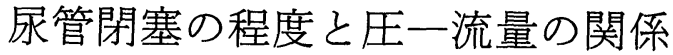

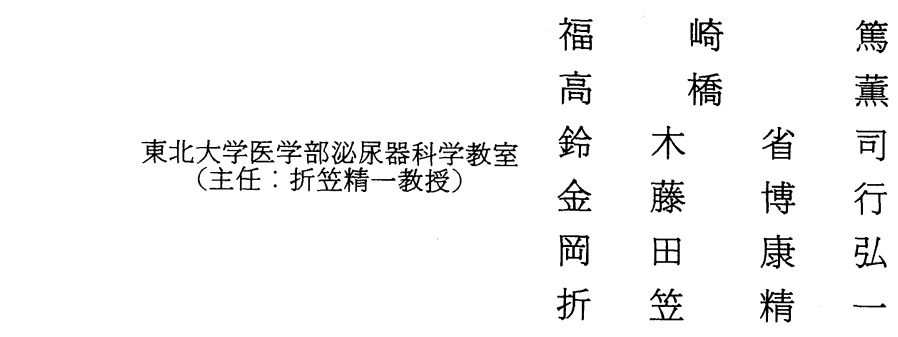

\section{PRESSURE-FLOW RELATIONSHIP AT VARYING DEGREES OF URETERAL OBSTRUCTION}

\author{
Atsushi Fukuzaki, Kaoru Takahashi, Shoji Suzuki, Hiroyuki Kanetoh \\ Yasuhiro Okada and Seiichi Orikasa \\ Department of Urology, Tohoku University School of Medicine \\ (Director: Prof. S. Orikasa)
}

The effect of increasing ureteral stenosis on intrapelvic pressure and renal function was studied theoretically and experimentally. Assuming that ureteral flow is laminar, pressure drop across the stenosis can be calculated by Poiseuille's law. Based on this theoretical model, severe ureteral stenosis may be necessary to produce high intra-pelvic pressure at physiological urine flow rate. For instance, a $22 \mathrm{G}$ injection needle sized stenosis is necessary to increase intrapelvic pressure more than $20 \mathrm{mmHg}$ at the flow rate of $10 \mathrm{ml} / \mathrm{min}$. Pressure-flow relationship at varving degrees of stenosis at cut end of dog ureter was similar to that theoretically calculated. In contrast, even a mild stenosis with theoretically negligible resistance might cause a significant intra-pelvic pressure elevation and produced hydronephrosis with disturbance of sodium and water reabsorption, if it was created in the intact ureter.

These results, together with previous experimental and clinical investigation, indicate that severe stenosis, which is rare in clinical hydronephrosis, should be necessary as a physical resistance to urine flow for significant increase of intra-pelvic pressure. We assume that functional cause may be predominant in most cases of clinical hydronephrosis.

\footnotetext{
要旨: 尿管狭窄の程度が腎孟内圧, 腎機能に与省影響について理論的及び動物実験にて検討した。尿 管内を尿が層流をなして流れるとすると，狭窄部での圧差は Poiseille の法則で算出できる。この理論に よると, 生理的な尿量の範囲内で腎掹内圧の著しい上昇をきたす為には高度な尿管の狭窄が必要と考兄 られる. 例えば, 流量 $10 \mathrm{ml} / \mathrm{min} て ゙ 20 \mathrm{mmHg}$ 以上の腎盂内圧の上昇をきたす為には $22 \mathrm{G}$ 注射針のサイズ の尿管の狭窄が必要といらことになる, 犬尿管断端に狭窄を作製し, 狭窄の程度と流量, 腎孟内压の関 係をみた結果, 理論的に算出したものと同様の值が得られた. これに対して, 理論的に物理的抵抗とは なり得ない程度の狭窄でも, 尿管内にあれば腎孟内圧の上昇を括こし, 水, ナトリウムの再吸収障害を 伴った水腎症の発症が認められた.

これらの結果より，腎孟内圧の有意な上昇を扣こすような物理的抵抗となる為には，極めて高度な狭 窄が必要であるが, 実際の水腎症では, このような狭窄は稀であり, 臨床的水腎症の多くは機能的要因 によるものと考えられた。
}

緒 言

先天性水腎症や巨大尿管症などでは腎孟尿管移行部
や尿管下端が細くなっていることが多く，この部分に 軽度〜中等度の狭窄の存在が疑われる。しかしながら， 
これら水腎, 水尿管症の主な原因は尿路の器質的閉塞 ではなく，尿輸送能障害による機能的閉塞によると考 えられている12). これらを機能的閉塞と診断する為に は, このような軽度〜中等度の狭窄が上部尿路内圧を 上昇させるような物理的抵抗となっていないことを証 明する必要がある。一方, 上部尿路の通過障害の診断 にはWhitakerの preseure flow study ${ }^{3}$ が現在広く用 いられているが, この方法には批判も多く, その生理 学的解釈には疑問も多(4)5). そこで我々は尿管の器質 的閉塞がどの程度であれば尿流に対して物理的抵抗と なり，腎に影響を与兄得るかを理論モデル及び動物実 験にて検討を加え, あわせて Whitaker Test の生理学 的意味について考察を扣こなった。

\section{実験方法}

\section{1. 理論的モデルによる検討}

一般に長さ $\mathrm{L}$, 半径 $\mathrm{R}$ の円管内を流れる層流をなす 粘性率 $\eta$, 流量 $\mathrm{Q}$ の流体の管両端での圧差 $\Delta \mathrm{P}$ は,

$$
\Delta \mathrm{P}=\frac{8 \eta \mathrm{L}}{\pi \mathrm{R}^{4}} \cdot \mathrm{Q}
$$

で算出できる（Poiseuille's Law)。この式を用いて流 量 $2 \mathrm{ml} / \mathrm{min}$ 粘性率 0.01 p.s. の流体が, 長さ $0.5 \mathrm{~mm}$ の管 内を流れるときの管両端での圧差を算出すると, 管の

Fig. 1 Theoretically calculated pressure differences across stenosis at varying degrees of stenosis. Flow rate, fluid viscosity and stenotic length were assumed $2 \mathrm{ml} / \mathrm{min}, 0.01 \mathrm{p} . \mathrm{s}$. and 0.5 $\mathrm{mm}$ respectively.

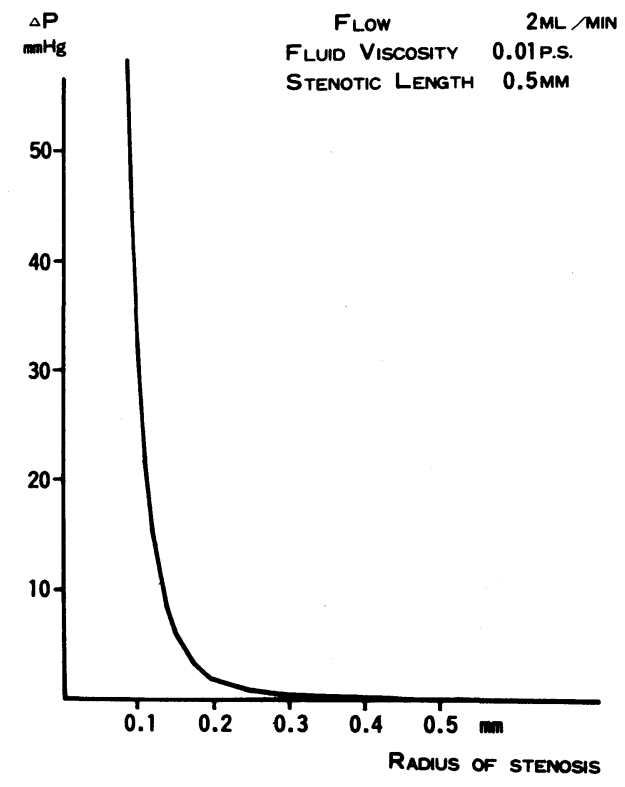

Fig. 2 Theoretically calculated pressure difference across injection needle of varying sizes.

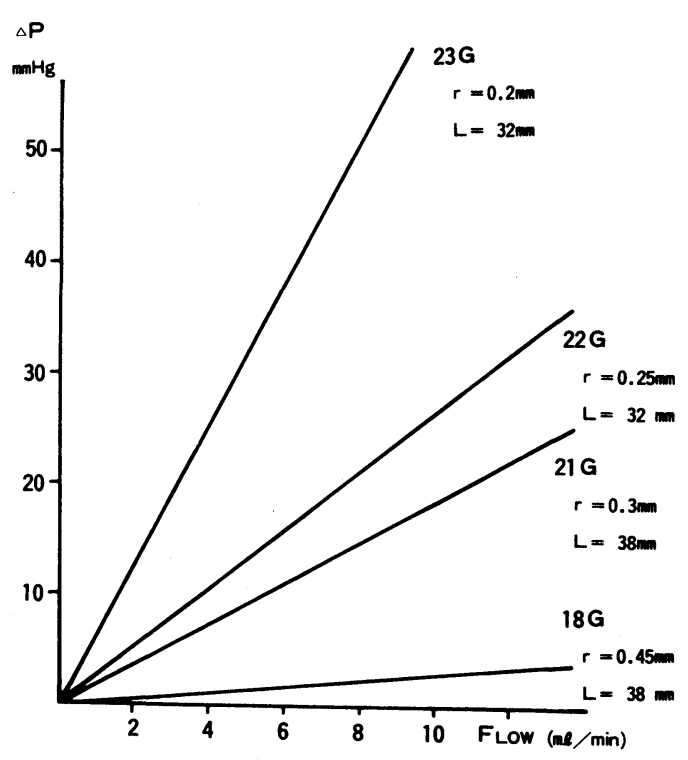

Fig. 3 Experimental model of stenosis at cut end of dog ureter.

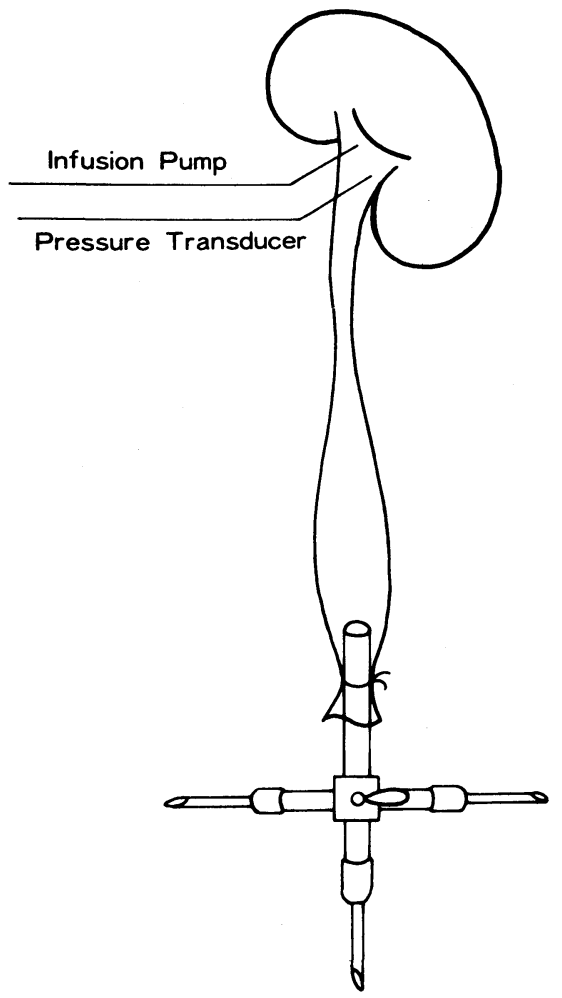


Fig. 4 Experimental model of stenosis in the lower part of dog ureter.

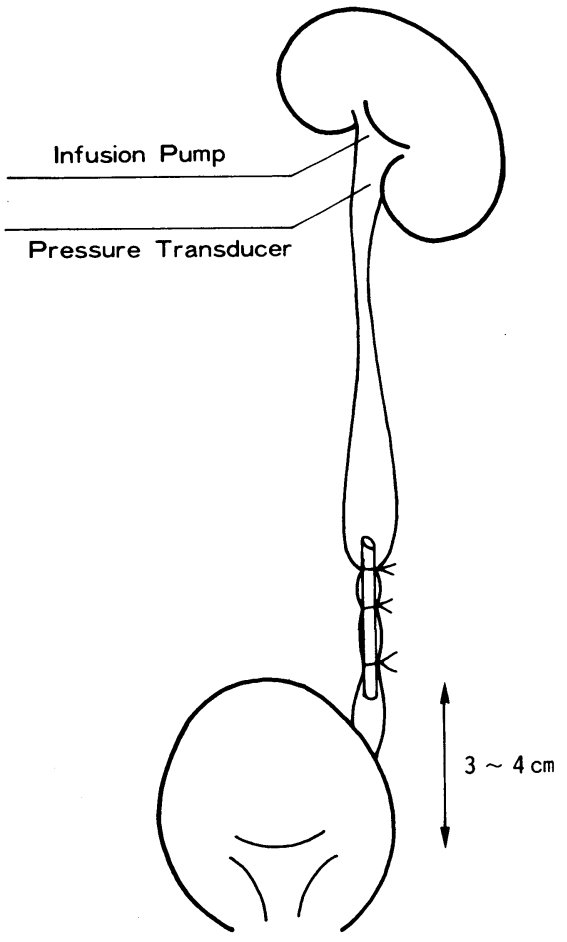

半径が $0.2 \mathrm{~mm}$ 以下になると急激に圧差が大きくなる ことがわかる (Fig. 1). 実際にこの程度の内径を有す る注射針 (テルモ社製) に粘性率0.01p.s.の生食を流し た際に得られる流量と圧の関係を理論的に算出する と, 流量 $10 \mathrm{ml} / \mathrm{min}$ で $20 \mathrm{mmHg}$ 以上の圧較差を得る為 には $22 \mathrm{G}$ 針よりも細い内径を必要とすることがわかる (Fig. 2).

\section{2. 急性実験による検討}

雑種成犬を用い，ペントバルビタール麻酔下に腹部 正中切開により左腎尿管に至り，左尿管を膀脱近位部 で切断して尿管断端に注射針を接続した抵抗器をとり つけた (Fig. 3). 抵抗器には三種類の注射針が接続可 能で，必要に応じて抵抗を変えることができるように なっている。な拄射針を除いた部分の抵抗は，実験 条件の範囲内では，殆ど無視できる程度のものである ことをあらかじめ確認した。腎は周囲を愛護的に剥離 した後，腎盂あるいは上部尿管を $21 \mathrm{G}$ 翼状針にて 2 カ 所穿刺し一方を注入用，もら一方を圧測定用とした。 まず尿量 $1 \mathrm{ml} / \mathrm{min}$ 以下の脱水条件下に，生食を流量を 変更させながら腎孟内に注入し，各サイズの注射針を 抵抗として用いた時の流量と上部尿路内圧との関係を 検討した．次に同様な実験モデルを用いてマンニトー ル負荷により尿量を増加させ各サイズの注射針を抵抗 として用いた時の上部尿路内圧と尿量, GFR との関係

Fig. 5 Effect of changing the size of obstruction at cut end of dog ureter on intrapelvic pressure at varying flow rates.
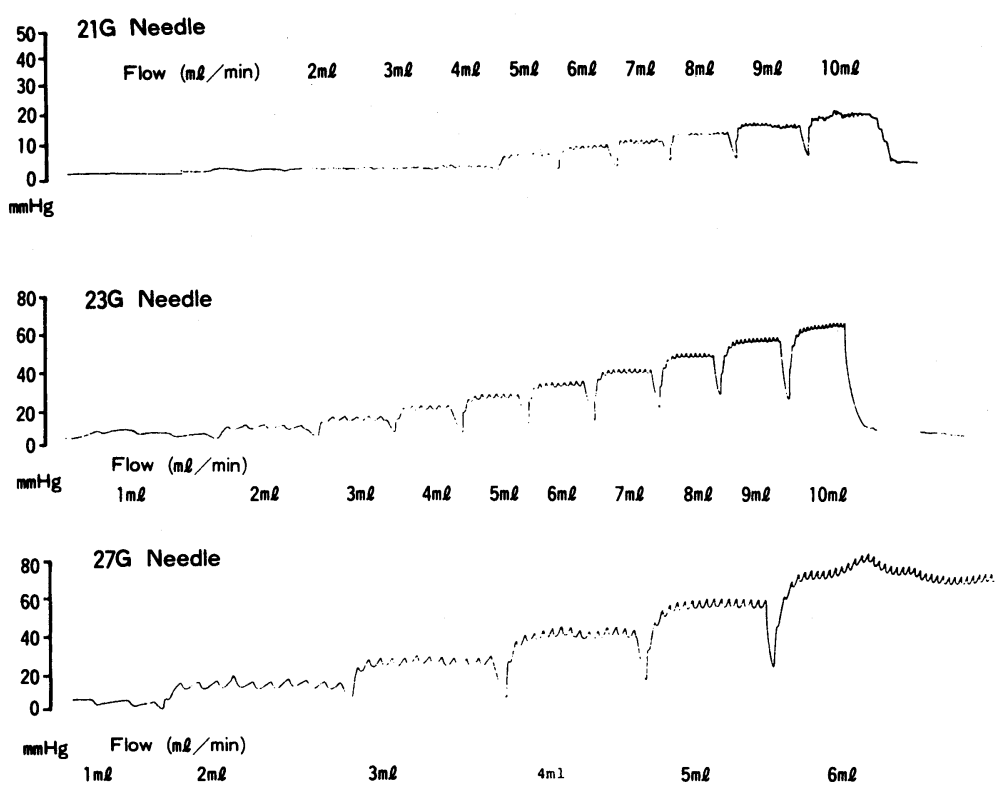
をみた。さらに下部尿管内に先端を鈍化させた $18 \mathrm{G}$ 針 （長さ $38 \mathrm{~mm}$ ，内径 $0.9 \mathrm{~mm}$ ）の金属部分を挿入固定した モデルで pressure flow studyを执こない，尿管断端に 抵抗を加皃た場合との相違について検討をおこなった (Fig. 4).

\section{3. 慢性動物実験による検討}

雑種雌成犬を用いて，ペントバルビタール麻酔下に 下腹部正中切開により左尿管を求め, 尿管内に先端を 鈍化させた $18 \mathrm{G}$ 針（長さ $38 \mathrm{~mm}$, 内径 $0.9 \mathrm{~mm}$ ) の金属部 分を挿入固定した。 2 週間に IVP 及び各種腎機能測定
の後，開腹下に pressure flow study を拈こなった。

$$
\text { 結果 }
$$

\section{1. 急性動物実験}

尿管断端に各サイズの注射針を抵抗として用いた際 の流量と上部尿路内圧の関係は，理論式を用いて算出 した值にほぼ一致した。すなわち, $21 \mathrm{G}$ 針(長さ $38 \mathrm{~mm}$, 内径 $0.6 \mathrm{~mm}$ ) では尿量 $10 \mathrm{ml} / \mathrm{min}$ で $16 \sim 18 \mathrm{mmHg}$ の圧 上昇が認められた（Fig．5)。また利尿下に抵抗を増大 させて検討した結果, 腎孟内圧が $30 \mathrm{mmHg}$ を超兄ると 尿量と GFR は著しく抑制された（Fig. 6,7）.

Fig. 6 Effect of changing the size of obstruction at cut end of dog ureter on upper ureteral pressure and urine flow rate in diuretic state.
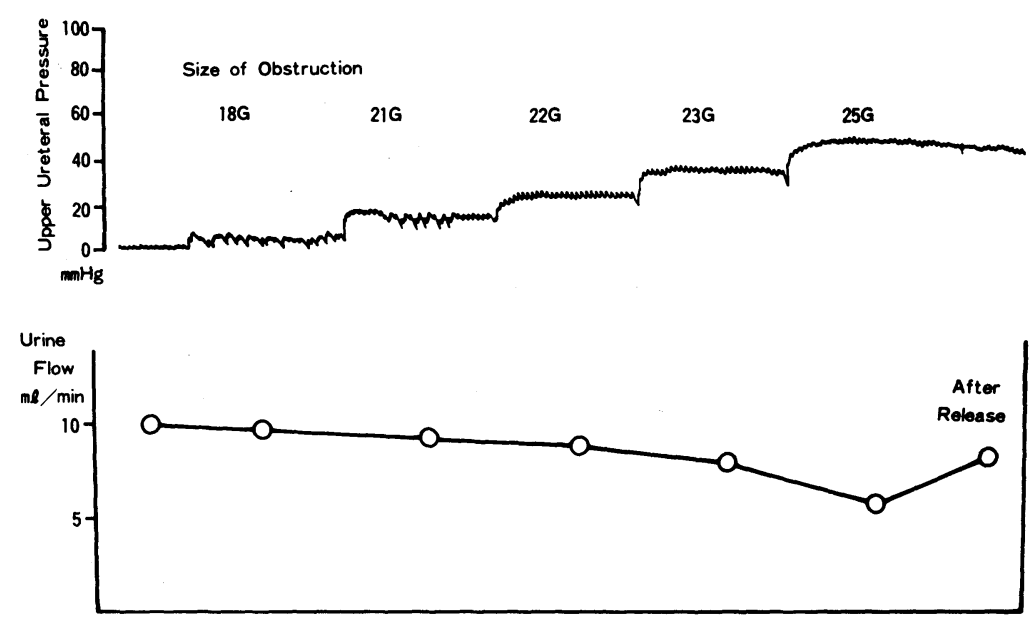

Fig. 7 Effect of acute incomplete obstruction with $27 \mathrm{G}$ injection needle at cut end of dog ureter on urine flow and Ccr in diuretic state.
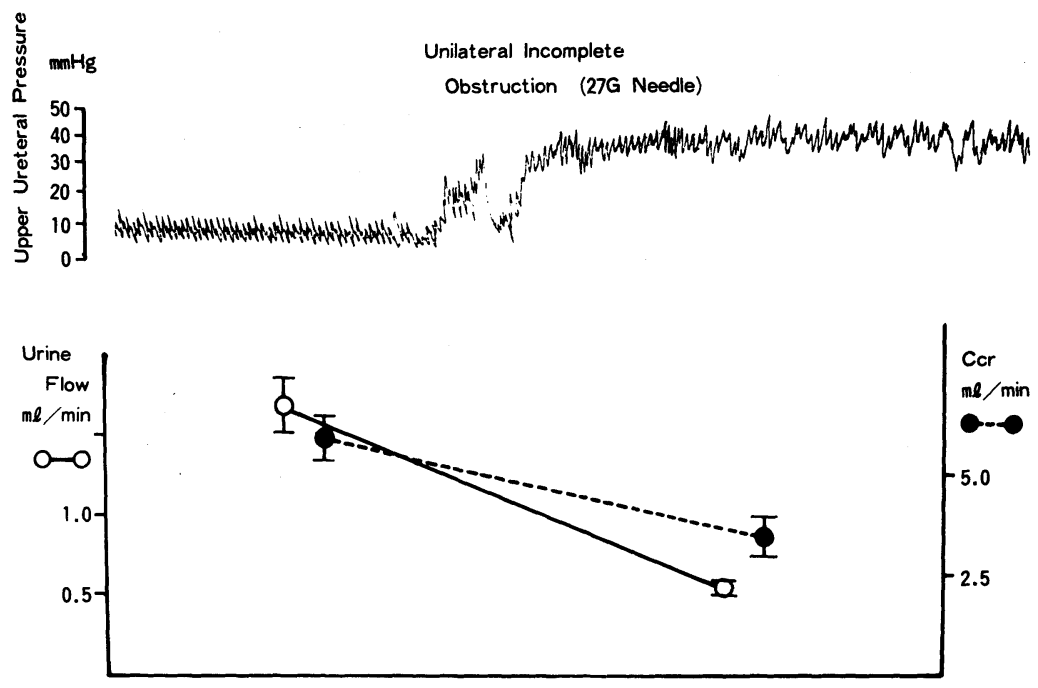
Fig. 8 Pressure-flow relationship in acute incomplete obstruction with 18G injection needle in the lower part of dog ureter.

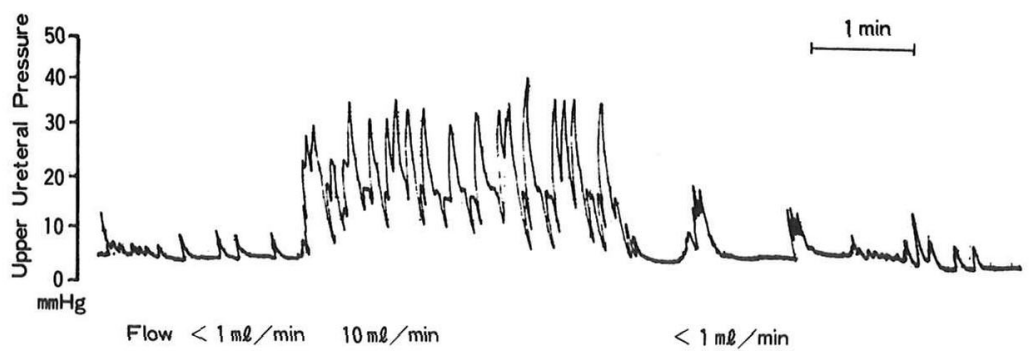

Fig. 9 IVP after 2 weeks of unilateral incomplete obstruction with $18 \mathrm{G}$ injection needle in the lower part of dog ureter.

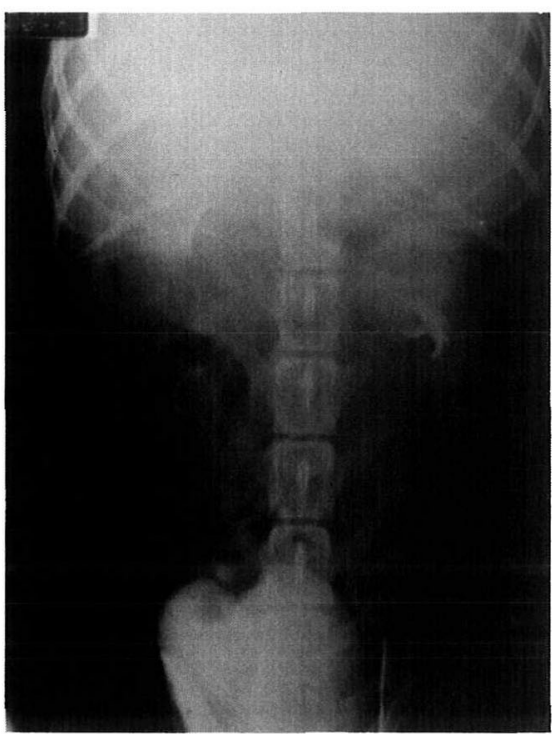

一方，理論的及び尿管断端に接続した場合には殆ど 物理的抵抗とならないと考光られる18G 針を尿管内に 留置すると，流量 $10 \mathrm{ml} / \mathrm{min}$ で著明な上部尿管の圧上 昇が認められた（Fig. 8).

\section{2. 慢性動物実験}

理論的及び尿管断端に抢いては物理的抵抗とならな いと考光られる $18 \mathrm{G}$ 針（長さ $38 \mathrm{~mm}$, 内径 $0.9 \mathrm{~mm}$ )を尿 管内に 2 週間留置すると，軽度ではあるが绿涪一様な 水腎の形成を認めた(Fig. 9). Pressure flow study で は, 流量 $10 \mathrm{ml} / \mathrm{min}$ で $20 \mathrm{mmHg}$ といら急性実験と同様 な圧上昇が得られた（Fig. 10）。また機能的には GFR の低下は殆ど認められなかったが，水とナトリウムの 再吸収障害の著しいことがうかがわれた（Fig. 11）。

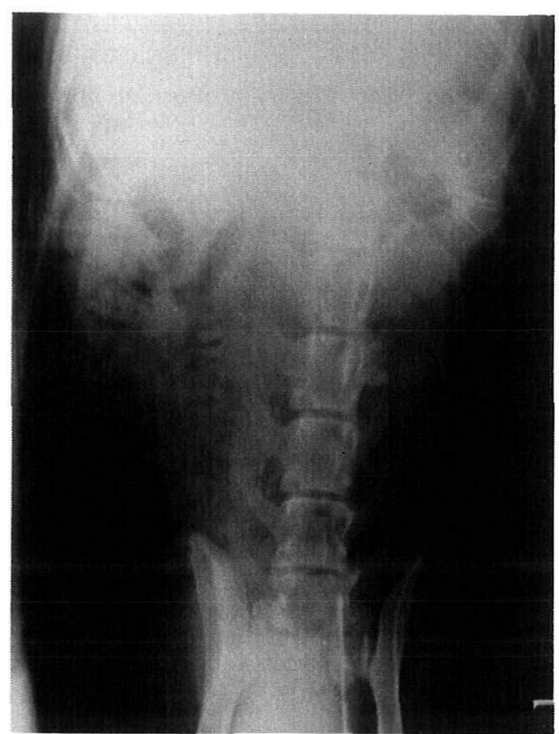

考按

腎孟尿管移行部閉塞による先天性水腎症や巨大尿管 症は，その多くが機能的閉塞によるとされている が1122)，その根拠は明らかではない，今回の我々の実験 結果によると，尿が尿管内を層流をなして流れるとす ると ${ }^{6)}$, 生理的な尿量の範囲内で腎に影響を与学を程 の腎盘内圧の著しい上昇をきたすような物理的抵抗と なる為には，かなり高度な尿管の狭窄が必要と考光ら れた。一方，理論的に物理的抵抗とならない程度の狭 窄でも，これが尿管の途中にあれば水腎を発症し得る ことが明らかとなった。これは狭窄部で尿管の蠕動が 障害され, urine volus の下部尿管への輸送が良好に行 われない為と考兄られる。実際の臨床的水腎症, 殊飞 先天性水腎症でも，尿管の狭窄はそれほど高度でない 
Fig. 10 Pressure-flow relationship of unilateral chronically obstructed canine model with $18 \mathrm{G}$ injection needle in the lower ureter for 2 weeks.
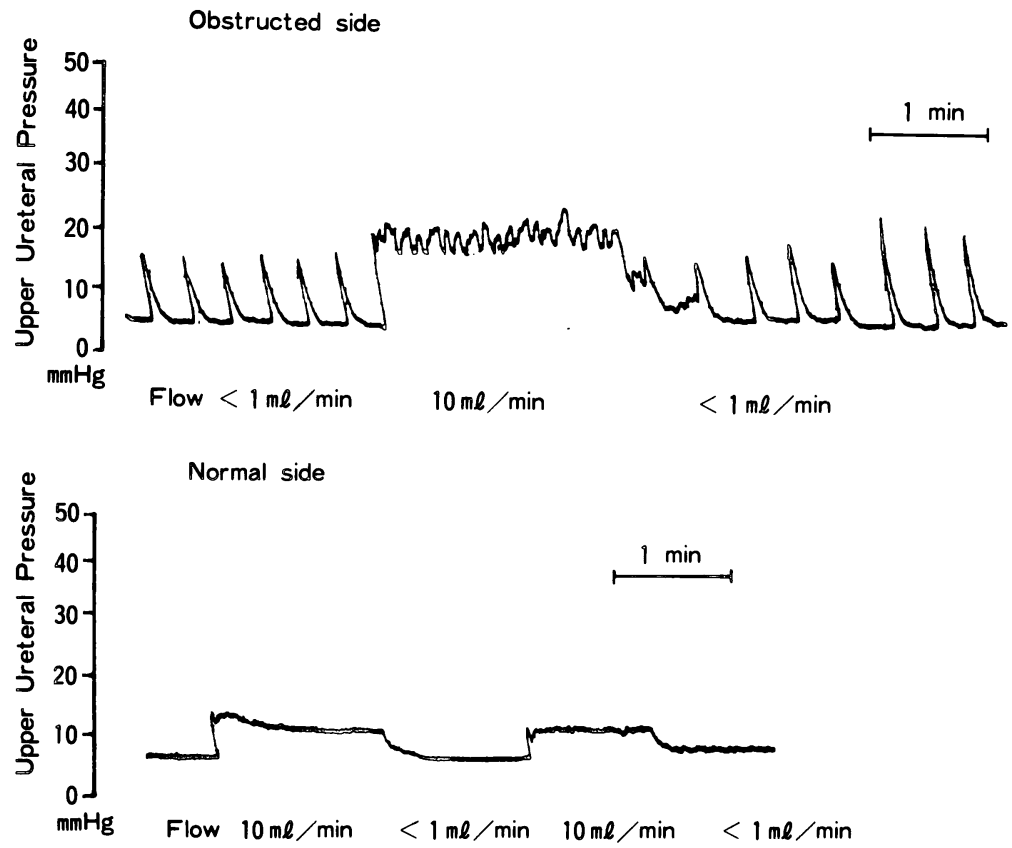

Fig. 11 Renal function of unilaterally obstructed canine model with $18 \mathrm{G}$ injection needle in the lower ureter for 2 weeks.

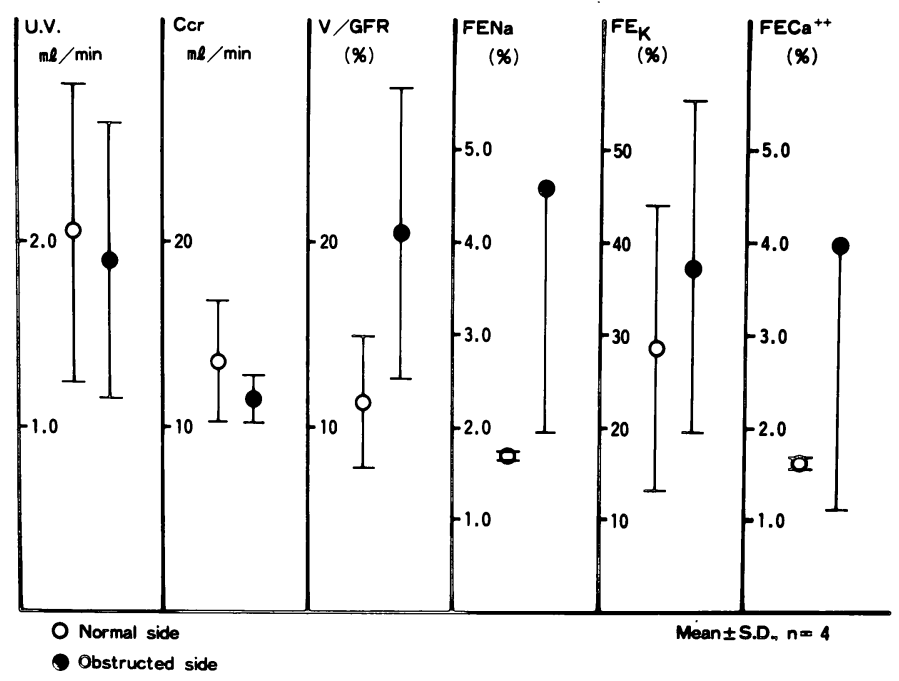

ものが多く、このような例では狭窄そのものよりも狭 窄部の蠕動障害により尿の輸送が障害されている可能 性が示唆される。しかしながら新生児期に認められる 先天性水腎症では，しばしば高度な尿管あるいは腎孟 尿管移行部の狭窄と著しい水腎傾向を示すものがあ

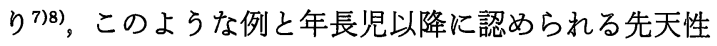
水腎症とは，予後に著しい相違のあることが察せられ る $^{910)}$ 。このような差は単に狭窄の程度の問題か, ある いは発生学的に異なる原因による為か11) 13), 今後の検 討を要するところである。 
また, いわゆる Whitaker Test は, $10 \mathrm{ml} / \mathrm{min}$ とい ら著しい流量下に腎孟内压上昇の有無を検討するもの であるが，このような著しい流量のもとでは尿管は完 全に液柱で満たされ，蠕動による尿輸送は無視できる 状態となっている ${ }^{14)}$. したがって尿あるいは注入液は 上部尿路と下部尿路の圧差によって流れると考兄ら れ，この状態で測定した腎孟内圧は，主として狭窄部 の物理的抵抗を反映している可能性が大きい。すなわ ち Whitaker Test で閉塞を確認されなくても機能的 閉塞は存在する可能性があり，またこのような機能的 閉塞に基づく腎孟内圧のわずかな上昇が腎に影響を与 える可能性は否定できない，我々は機能的閉塞の有無 をみるためには，より少ない流量で尿輸送能を検討す る必要があると考えて打り, その詳細についてはあら ためて報告する。

\section{結 語}

尿管の器質的閉塞がどの程度あれば, 腎孟内圧の上 昇をさたすよらな物理的抵抗となり得るかを検討し た。

1）物理的には生理的尿量の範囲内で $20 \mathrm{mmHg}$ 以上 の腎血内圧の上昇をきたす為には $22 \mathrm{G}$ 針程度の高度の 狭窄が必要と考えられた。

2) 犬尿管断端に注射針を用いて作製した抵抗器を 接続して検討した結果, 理論的值と同様な圧流量関係 が得られた。

3）物理的抵抗としては問題とならない程度の $18 \mathrm{G}$ 針を犬尿管内に留置すると, 腎盂内圧の上昇と, 水腎 症の発症を認めた。

以上より，上部尿管内圧の著しい上昇をきたすよう な物理的抵抗となる為には, かなり高度な器質的閉塞 が必要であり, 臨床的水腎症の多くは機能的閉塞によ るものと考觉られた。

\section{References}

1) Whitaker, R.H. : Some observations andtheories on the wide ureter and hydronephrosis. Brit. J. Urol., 47, 377-385, 1975.

2) Djurhuus, J.C., Mortensen, S.O., Mauritzen, K. and Nerstom, B.: Electrophysiological investigation of hydronephrosis in children. J. Urol.,
126, 759-762, 1981.

3) Whitaker, R.H.: Method of assessig obstruction in dilated ureters. Brit. J. Urol., 45, 15-22, 1973.

4) Toguri, A.G. and Founier, G.: Factors influencing the pressure-flowperfusion system. J. Urol., 127, 1021-1023, 1982.

5) Mortensen, J., Djurhuus, J.C., Laursen, H. and Bisballe, S.: The relatationship bewteen pressure and flow in thenormal pig renal pelvis. An experimental study of the range of normal pressures. Scand. J. Urol. Nephrol., 17, 369-372, 1983.

6) Bullock, K.N.: The biomechanical principles of upper urinary tract pressure-flow studies. Brit. J. Urol., 55, 136-139, 1983.

7) Bejjani, B. and Belman, A.B.: Ureteropelvic junction obstruction in newborns andinfants. J. Urol., 128, 770-773, 1982.

8) Valayer, J. and Adda, G.: Hydronephrosis due to pelviureteric junction obstruction in infancy. Brit. J. Urol., 54, 451-454, 1982.

9) Samuelson, U., Granerus, G., Bjures, J., Hagberg, S. and Hjalmas, K.: Renal function in idiopathic hydronephrosis in children. Scand. J. Urol. Nephrol., 18, 135-141, 1984.

10) Roth, D.R. and Gonzales, E.T. Jr.: Management of ureteropelvic junction obstruction in infants. J. Urol., 129, 108-110, 1983.

11) Ruano-Gill, D., Coca-payeras, A. and TejedoMateu, A.: Obstruction and normal recanalization of the ureter in the human embryo. Its relation to congenital ureteric obstruction. Eur. Urol., 1, 287-293, 1975.

12) Ostling, K.: Tne genesis of hydronephrosis perticulary with regard to the changes at the ureteropelvic junction. Acta Chir. Scand., 86 Suppl, 721-122, 1942.

13) Allen, T.D.: Cingenital ureteral strictures. J. Urol., 104, 196-204, 1970.

14) Woodside, J.R. and Borden, T.A.: The pressure-flow relationship of the normal ureter. Invest. Urol., 18, 82-83, 1980.

（1984年12月 4 日受付） 